\title{
Changes during Cooking Processes in 6 Varieties of Andean Potatoes (Solanum tuberosum ssp. Andinum)
}

\author{
Maria E. Jimenez, Analia M. Rossi, Norma C. Sammán* \\ Instituto Superior de Investigaciones Biológicas (INSIBIO), CONICET-UNT, e Instituto de Química Biológica “Dr. \\ Bernabé Bloj", Facultad de Bioquímica, Química y Farmacia, UNT, Chacabuco, Tucumán, Argentina \\ Email: "nsamman@arnet.com.ar
}

Received 5 January 2015; accepted 18 March 2015; published 23 March 2015

Copyright (C) 2015 by authors and Scientific Research Publishing Inc.

This work is licensed under the Creative Commons Attribution International License (CC BY). http://creativecommons.org/licenses/by/4.0/

cc) (i) Open Access

\section{Abstract}

The value of the native potato varieties grown in Argentinean northwest lies both in their fundamental role as a source of food for the population and in their potential for the development of new products. The aim of this work was to study the changes produced by two common cooking processes (boiling and frying) on the nutritional, textural and functional characteristics of five Andean potatoes varieties. The cooking process (boiling) does not significantly affect the composition of potatoes, but there are losses of vitamin C; a greater loss was observed when they were boiled shelled. In frying potatoes vitamin $C$ is completely destroyed. Resistant starch values between 0.90 and $4.58 \mathrm{~g} / 100 \mathrm{~g}$ of potato were found for raw Andean varieties; they decreased during the cooking process (boiled) $(0.15$ to $0.54 \mathrm{~g} / 100 \mathrm{~g}$ of potato) and increased again to be stored for $48 \mathrm{~h}$ at $4^{\circ} \mathrm{C}(0.73-1.88 \mathrm{~g} / 100 \mathrm{~g}$ of potato $)$. The frying process produced an increment in energy value between $92 \%$ and $148 \%$ according to variety. Regarding to the fracture strength and hardness, no significant differences were observed between the Andean varieties and the control (Spunta) at the initial or final stages, but there were differences during the intermediate stages.

\section{Keywords}

Andean Potato, Vitamin C, Cooking Processes, Nutrient Retention, Energy Value, Textural Properties

\footnotetext{
*Corresponding author.
} 


\section{Introduction}

Potatoes are tubers whose nutritional value has been underestimated. They are an important food source worldwide, mainly as a source of energy and some micronutrients. According to statistics from FAOSTAT FAO [1], potatoes supplied $2 \%$ of food energy in the world, being less important than rice, wheat and maize, which represent 20\%, 18\%, and 5\% dietary energy supply (DES), respectively. However, there are regions where the most significant contribution is due to their high consumption. They are also one of the richest sources of antioxidants in the human diet, including ascorbic acid (8 - $54 \mathrm{mg} / 100 \mathrm{~g})$, polyphenols (123 - $441 \mathrm{mg} / 100 \mathrm{~g})$, carotenoids (up to $0.4 \mathrm{mg} / 100 \mathrm{~g}$ ) and tocopherols (up to $0.3 \mathrm{mg} / 100 \mathrm{~g}$ ) [2]-[4]. The potato has become a key food for vitamin $\mathrm{C}$ in many regions of the world because of their high consumption levels, which, associated with its content of vit $\mathrm{C}$, contribute in a great manner to reaching the requirements of the nutrient. Only $50 \%$ of the potato world's production is consumed fresh. The remainder is used to obtain foodstuffs and industrial food ingredients; feed for cattle, pigs and poultry; starch for industrial use and seeds for the next sowing [5].

Modern methods of food production play an important role in reducing the genetic diversity of plants and animals, whereby FAO [6] argues that it is necessary to take immediate action to promote sustainable diets and food biodiversity in order to improve the health population and conserve the planet. Sustainable diets include foods with lower carbon footprint and water consumption, promoting the use of food biodiversity, including traditional and local foods, with many species and nutrient-rich varieties [6]. The value of the Andean potato varieties (Solanum tuberosum ssp. Andigenum) grown in the Argentinean northwest lies both in their fundamental role as a source of food for the population and in their potential for development of new products. These varieties have different physiognomic and organoleptic characteristics and adaptation capacity to different ecological zones in the Andean region, which are important for their use in the genetic improvement of potatoes. The Andean potato varieties are adapted to high heights ranging from 1800 to $3800 \mathrm{~m}$ above sea level; this influences their agronomic characteristics. The yield varies from 8000 to $18,000 \mathrm{~kg} / \mathrm{ha}$ depending on the variety and they also have different resistances to plagues. Among the parameters that determine the tubers quality, the most relevant is the total solids and protein content of fresh product, and sensorial characteristics of processed products. The study of the characteristics of different varieties grown in the region can help to promote them and expand the possibilities of using the potato in gastronomy as well as opening new markets for consumption.

Starch is the main component in potatoes' dry matter; this is important for food industry due to the effect it has on the physical, functional and organoleptic properties of food. In the last years, search for alternative sources of starch was deepened to the conventional maize and wheat, which possess the desirable functional properties for industrial application [7] [8].

Based on its digestibility, starch is classified into readily digestible starch (RDS), slowly digestible starch (SDS), and resistant starch (RS) [9]. RS is the portion that passes undigested through the small intestine of healthy individuals and is fermented in the large intestine. RS is classified into four groups: RS1, RS2, RS3 and RS4 [10]. RS1 is the starch in unprocessed food, physically inaccessible. RS2 is the starch with a natural status and a granular form, and RS3 is formed when foods containing starch are cooked and cooled-process during which the starch granules undergo gelatinization and retrogradation. RS4 included those starch modified by chemical treatments [11]. RS is important in human nutrition due to the positive influence it has on the digestive tract, microbial flora, the level of blood cholesterol, glycemic index and diabetes control [12]. Hence, besides its potential as an ingredient in food formulation, RS is considered inside the category of novel functional compounds.

Potato varieties differ from one another in their texture after cooking. This feature, which involves consistency, tendency to rupture, flouriness, dryness and structure, frequently determines the use to be given to the product [13]. According to McGregor [14], the texture of cooked tubers is affected by their individual chemical components, as well as by the interactions among them during storage, cooking, grinding or processing. The texture of cooked potato products is associated with starch gelatinization and retrogradation processes [15]. The texture profile analysis method (TPA) may be used to find a good approximation to the mastication index of a food product with a single objective test, and the only condition is that the material should be homogeneous [16] [17]. The texture parameters defined by the TPA method, such as hardness, elasticity, cohesiveness, adhesiveness and masticability, may determine the quality of a food product.

A common way to consume potatoes is boiled and fried. Frying is a widespread method in the food industry. It improves the hygienic quality of food by the inactivation of pathogenic microorganisms, develops pleasant organoleptic characteristics in food through non-enzymatic browning reactions and may increase the digestibili- 
ty and bioavailability of nutrients in the digestive tract. It can be defined as the food cooking and dehydration by immersion in hot medium-oil. The high temperatures and the presence of water, oil and/or hot air cause several changes of food components during processing: hydrolytic and interesterification reactions, enzymatic and nonenzymatic browning, oxidation, oil degradation during frying, formation of flavor or smell-taste perception, degradation of natural pigments and formation of colored compounds.

Food composition databases should contain information about the food as ingested; and potatoes are eaten cooked [18]. The interaction between the raw material and the cooking procedure has not been studied in depth, even when the heat treatment has a significant impact on the physic-chemical and textural characteristics and food composition [19].

The aim of this work was to study the changes produced by two common cooking processes (boiling and frying) on the nutritional, textural and functional characteristics of five Andean potatoes varieties.

\section{Materials and Methods}

\subsection{Materials}

Five varieties of Andean potatoes (S. tuberosum ssp. Andigenum) were studied: Collareja, Runa, Churqueña, Imilla Colorada and Revolution, purchased from Agricultural and Artisanal Cooperative Union Quebrada and Valleys (CAUQueVa). Crops were brought by local producers to the collection and these were classified and kept refrigerated. Six samples of $2 \mathrm{Kg}$ for each variety were selected (two samples of each at three different times) and kept refrigerated until use. All determinations were performed in triplicate. The Spunta (S. tuberosum) variety was used as a reference because it is the most widespread commercially. It was provided by the Estación Experimental Agrícola “Obispo Colombres”, Tafí del Valle, Tucumán. Argentina.

\subsection{Chemical Analysis}

The samples were peeled using a kitchen vegetable peeler, and were cut into thin strips. All the analytical determinations were performed using AOAC methods [20]. Moisture was determined by drying in convection oven AOAC 925.23 method. Lipid content was determined according to Soxlet method, AOAC 963.15. Total protein content was determined using Kjeldahl (BUCHI DIGESTIÓN UNIT K-435) procedure with a nitrogento-protein conversion factor of 6.25, AOAC 991.20 method. Ash analysis used a carbonization at $550^{\circ} \mathrm{C}$ (Mufle furnace), AOAC 945.46 method. Dietary fiber (soluble and insoluble) was determined by AOAC 985.29 method.

\subsubsection{Vitamin C}

It was determinate according to Correa de Souza et al. [21], using a Gilson HPLC system with a C18 column and a UV detector $(254 \mathrm{~nm})$. The mobile phase was an aqueous solution of $\mathrm{H}_{2} \mathrm{SO}_{4}(\mathrm{pH}=2.5)$ with an isocratic flow of $0.7 \mathrm{~mL} / \mathrm{min}$. Ascorbic acid was used as standard (SIGMA ${ }^{\circledR}$ ).

For vitamin $C$ extraction of the food matrix, the sample was mashed and homogenized with a solution of meta-phosphoric $(0.3 \mathrm{M})$ and acetic acid $(1.4 \mathrm{M})$. The extracts were filtered and used for their quantification.

\subsubsection{Loss of Vitamin C by the Cooking Process}

Potatoes (with and without shell) were placed in a container of boiling water. They were boiled for $20 \mathrm{~min}$. After this time, the potatoes were removed and the vitamin $\mathrm{C}$ content was determined. The factor of retention of Vitamin $\mathrm{C}$ was calculated according to the recommendations of FAO [6], by applying the yield factors and the following formula:

RFVitC $=$ VitC $[\mathrm{mg} / 100 \mathrm{~g}$ boiled potato $] \times \mathrm{YF} \times 100$

VitC $[\mathrm{mg} / 100 \mathrm{~g}$ raw potato]

$\mathrm{YF}=$ weight boiled potato $(\mathrm{g}) /$ weight raw potato $(\mathrm{g})$

\subsection{Total and Resistant Starch Content}

\subsubsection{Total Starch}

It was determined according to the technique described by McCleary et al. [22]. 


\subsubsection{Resistant Starch}

It was determined in raw potatoes, freshly boiled potatoes (boiled for 20 minutes) and boiled potatoes stored at $5^{\circ} \mathrm{C}$ for 48 hours, by the technique of Goñi et al. [23].

\subsection{Deep-Frying}

The potatoes were cut $(1.2 \times 1.2 \times 3.0 \mathrm{~cm})$ with a commercial potato cutter (French FryCutter). For the frying process, a domestic electric fryer (Phillips) with glass aluminum, $2.5 \mathrm{~L}$ capacity and temperature controller was used. The frying time was $5 \mathrm{~min} / 300 \mathrm{~g}$ of food at an initial oil temperature of $196^{\circ} \mathrm{C} \pm 2^{\circ} \mathrm{C}$, the temperature and cooking time was previously set to obtain a product of acceptable color and texture. Partially hydrogenated vegetable oil ( ${ }^{\circledR}$ Superfry) was used, the oil/feed relation was $833 \mathrm{~mL} / 100 \mathrm{~g}$.

All determinations were performed in quadruplicate.

\section{Fat Absorption (FA)}

It was calculated using Bognár \& Piekarski [24] formula.

Fat absorption (\%) $=$ Fat fried food $(\%) \times$ Yield - Raw food fat $(\%)$

Yield $=$ Weight fried food/weight raw food

\subsection{Cooking Process}

Potatoes of similar sizes were selected, weighed and dipped in boiling water, whole and with their skin, for 5, 10 , 15 and 20 minutes after the water began to boil again. When each cooking period was completed, the potatoes were brought to room temperature by immersion in cold water. The food/water ratio was $90-210 \mathrm{~g} / \mathrm{L}$.

\subsubsection{Cooking Time}

The cooking time was established as the required to reach the lowest compression strength needed to attain $50 \%$ of the thickness of the original slice [15].

\subsubsection{Textural Properties}

Three potatoes were taken from each established boiling time batch and two 1-centimeter-thick slices were cut. Fracture strength and hardness were measured with a CNS Farmell QTS 25 Texture Analyzer belonging to the National University of Salta.

The established compression distance was $50 \%$ of the total height of the slices $(0.5 \mathrm{~cm})$, with a speed of 50 $\mathrm{mm} / \mathrm{min}$ and a cell pressure of $10 \mathrm{~kg}$.

\subsubsection{Water Absorption Capacity}

Samples of potatoes boiled for 5, 10, 15 and 20 minutes were brought to room temperature by immersion in cold water, dried and weighed again.

\subsubsection{Loss of Soluble Solids}

Two aliquots of $40 \mathrm{~mL}$ were taken of the cooking water and dried at $105^{\circ} \mathrm{C}$.

\section{Results and Discussion}

\subsection{Changes in the Composition of Potatoes by Cooking Processes}

Table 1 shows the composition of raw [25] and boiled potatoes. It can be seen that the cooking process does not significantly affect the composition. These results are consistent with the low values of water absorption and loss of soluble solids shown in Figure 1. The potato is a tuber that is not ingested raw; to improve palatability and digestibility it is subjected to cooking processes like boiling, frying or roasting. These operations cause nutrient loss. Vitamin C is heat sensitive and highly soluble and, therefore, its retention rate was determined after boiling processes. Table 2 shows the Vitamin $\mathrm{C}$ content of potatoes boiled in shell and shelled and the percentage retention in each case. Vitamin $\mathrm{C}$ retention was higher when tubers were boiled in shell. In fries potatoes vitamin $\mathrm{C}$ is completely destroyed by the high temperatures of the cooking process. The boiling process affects the vitamin C content causing losses between $27.41 \%$ and $64.18 \%$, depending on variety. Burgos et al. [26] 
Table 1. Proximal composition of raw, boiled and fried potatoes.

\begin{tabular}{|c|c|c|c|c|c|c|c|}
\hline \multicolumn{8}{|c|}{ Raw potato } \\
\hline \multirow{2}{*}{ Variety } & \multirow{2}{*}{$\begin{array}{c}\text { Moisture } \\
\text { (g/100g potato) }\end{array}$} & \multirow{2}{*}{$\begin{array}{c}\text { Energy } \\
(\text { Kcal/kJ) }\end{array}$} & Protein & Lipid & Ash & Total fibre & Carbohydrate $^{\mathrm{b}}$ \\
\hline & & & \multicolumn{5}{|c|}{$(\mathrm{g} / 100 \mathrm{~g} \text { potato })^{\mathrm{a}}$} \\
\hline Spunta & $82.94 \pm 1.49$ & $57 / 239$ & $1.98 \pm 0.78$ & $0.05 \pm 0.03$ & $0.84 \pm 0.14$ & $2.01 \pm 0.10$ & 12.18 \\
\hline Collareja & $75.87 \pm 3.69$ & $82 / 344$ & $2.47 \pm 0.51$ & $0.12 \pm 0.04$ & $1.16 \pm 0.03$ & $2.57 \pm 0.17$ & 17.81 \\
\hline Revolución & $78.28 \pm 1.82$ & $75 / 314$ & $0.85 \pm 0.06$ & $0.07 \pm 0.03$ & $1.01 \pm 0.07$ & $1.95 \pm 0.09$ & 17.84 \\
\hline Churqueña & $73.58 \pm 2.75$ & $92 / 385$ & $2.23 \pm 0.73$ & $0.47 \pm 0.42$ & $1.02 \pm 0.03$ & $2.84 \pm 0.13$ & 19.86 \\
\hline I. Colorada & $73.07 \pm 0.63$ & $97 / 406$ & $2.55 \pm 0.41$ & $0.51 \pm 0.28$ & $1.35 \pm 0.24$ & $1.98 \pm 0.11$ & 20.54 \\
\hline Runa & $74.91 \pm 3.69$ & $85 / 356$ & $1.60 \pm 0.50$ & $0.26 \pm 0.11$ & $0.89 \pm 0.23$ & $3.30 \pm 0.15$ & 19.04 \\
\hline \multicolumn{8}{|c|}{ Boiled potato } \\
\hline \multirow{2}{*}{ Variety } & \multirow{2}{*}{$\begin{array}{c}\text { Moisture } \\
\text { (g/100g potato) }\end{array}$} & \multirow{2}{*}{$\begin{array}{l}\text { Energy } \\
(\mathrm{Kcal} / \mathrm{kJ})\end{array}$} & Protein & Lipid & Ash & Total fibre & Carbohydrate $^{b}$ \\
\hline & & & \multicolumn{5}{|c|}{$(\mathrm{g} / 100 \mathrm{~g} \text { potato })^{\mathrm{a}}$} \\
\hline Spunta & $82.97 \pm 0.00$ & $57 / 239$ & $1.97 \pm 0.00$ & $0.05 \pm 0.01$ & $0.84 \pm 0.050$ & $2.00 \pm 0.12$ & 12.17 \\
\hline Collareja & $76.60 \pm 0.25$ & 79/331 & $2.40 \pm 0.03$ & $0.12 \pm 0.00$ & $1.13 \pm 0.01$ & $2.50 \pm 0.03$ & 17.25 \\
\hline Revolución & $78.74 \pm 0.04$ & $74 / 310$ & $0.83 \pm 0.00$ & $0.07 \pm 0.02$ & $0.99 \pm 0.07$ & $1.91 \pm 0.05$ & 17.46 \\
\hline Churqueña & $73.96 \pm 0.10$ & $91 / 381$ & $2.20 \pm 0.01$ & $0.46 \pm 0.06$ & $1.01 \pm 0.09$ & $2.80 \pm 0.01$ & 19.57 \\
\hline I. Colorada & $73.57 \pm 0.07$ & 95/398 & $2.50 \pm 0.01$ & $0.50 \pm 0.02$ & $1.32 \pm 0.11$ & $1.94 \pm 0.11$ & 20.17 \\
\hline Runa & $75.40 \pm 0.13$ & $83 / 348$ & $1.57 \pm 0.01$ & $0.25 \pm 0.00$ & $0.87 \pm 0.01$ & $3.21 \pm 0.02$ & 18.70 \\
\hline \multicolumn{8}{|c|}{ Fried potato } \\
\hline \multirow{2}{*}{ Variety } & \multirow{2}{*}{$\begin{array}{c}\text { Moisture } \\
\text { (g/100g potato) }\end{array}$} & \multirow{2}{*}{$\begin{array}{l}\text { Energy } \\
(\mathrm{Kcal} / \mathrm{kJ})\end{array}$} & Protein & Lipid & Ash & Total fibre & Carbohydrate $^{b}$ \\
\hline & & & \multicolumn{5}{|c|}{$(\mathrm{g} / 100 \mathrm{~g} \text { potato })^{\mathrm{a}}$} \\
\hline Spunta & $64.75 \pm 1.58$ & $141 / 591$ & $4.09 \pm 0.15$ & $4.79 \pm 0.52$ & $1.74 \pm 0.08$ & $4.15 \pm 0.32$ & 20.48 \\
\hline Collareja & $57.74 \pm 1.59$ & $176 / 737$ & $4.33 \pm 0.13$ & $6.72 \pm 1.71$ & $2.03 \pm 0.10$ & $4.50 \pm 0.23$ & 24.68 \\
\hline Revolución & $62.49 \pm 2.43$ & $159 / 666$ & $1.47 \pm 0.09$ & $6.01 \pm 1.22$ & $1.74 \pm 0.22$ & $3.37 \pm 0.14$ & 24.92 \\
\hline Churqueña & $57.04 \pm 5.92$ & $177 / 742$ & $3.63 \pm 0.10$ & $6.20 \pm 0.76$ & $1.66 \pm 0.17$ & $4.62 \pm 0.42$ & 26.85 \\
\hline I. Colorada & $55.33 \pm 1.87$ & $186 / 779$ & $4.22 \pm 0.21$ & $5.92 \pm 1.25$ & $2.24 \pm 0.13$ & $3.28 \pm 0.26$ & 29.01 \\
\hline Runa & $52.12 \pm 1.50$ & $186 / 779$ & $3.05 \pm 0.30$ & $5.45 \pm 0.51$ & $1.70 \pm 0.05$ & $6.30 \pm 0.20$ & 31.38 \\
\hline
\end{tabular}

${ }^{\mathrm{a}}$ Mean \pm standard deviation; $\mathrm{n}=3$; ${ }^{\mathrm{b} C a r b o h y d r a t e ~=~} 100-$ (Moisture + Protein + Lipid + Ash + Total fiber).

Table 2. Retention of vitamin C in boiled potatoes.

\begin{tabular}{|c|c|c|c|c|c|}
\hline \multirow[b]{2}{*}{ Variety } & \multirow{2}{*}{$\begin{array}{c}\text { Raw } \\
\text { Vitamin } \mathrm{C}^{\mathrm{a}} \\
\text { (mg/100g potato) }\end{array}$} & \multicolumn{2}{|c|}{ Boiled in shell } & \multicolumn{2}{|c|}{ Boiled shelled } \\
\hline & & $\begin{array}{c}\text { Vitamina } C^{a} \\
\text { (mg/100g potato) }\end{array}$ & $\begin{array}{l}\text { Retention } \\
\text { (\%) }\end{array}$ & $\begin{array}{c}\text { Vitamina } C^{a} \\
\text { (mg/100g papa) }\end{array}$ & $\begin{array}{l}\text { Retention } \\
\text { (\%) }\end{array}$ \\
\hline Spunta & $28.58 \pm 1.93$ & $17.65 \pm 0.87$ & 63.19 & $16.35 \pm 0.42$ & 58.52 \\
\hline Collareja & $15.61 \pm 0.04$ & $8.36 \pm 0.53$ & 54.91 & $5.45 \pm 0.55$ & 35.82 \\
\hline Revolución & $11.00 \pm 2.76$ & $7.97 \pm 1.17$ & 73.56 & $6.58 \pm 0.11$ & 60.68 \\
\hline Churqueña & $12.74 \pm 0.03$ & $10.78 \pm 1.29$ & 86.09 & $8.11 \pm 0.21$ & 64.74 \\
\hline Imilla Colorada & $9.01 \pm 0.07$ & $7.25 \pm 0.37$ & 81.85 & $6.42 \pm 0.11$ & 72.59 \\
\hline Runa & $10.86 \pm 0.93$ & $7.50 \pm 0.42$ & 68.02 & $5.00 \pm 0.14$ & 46.91 \\
\hline
\end{tabular}

${ }^{\mathrm{a}}$ Mean \pm standard deviation; $\mathrm{n}=3$. 


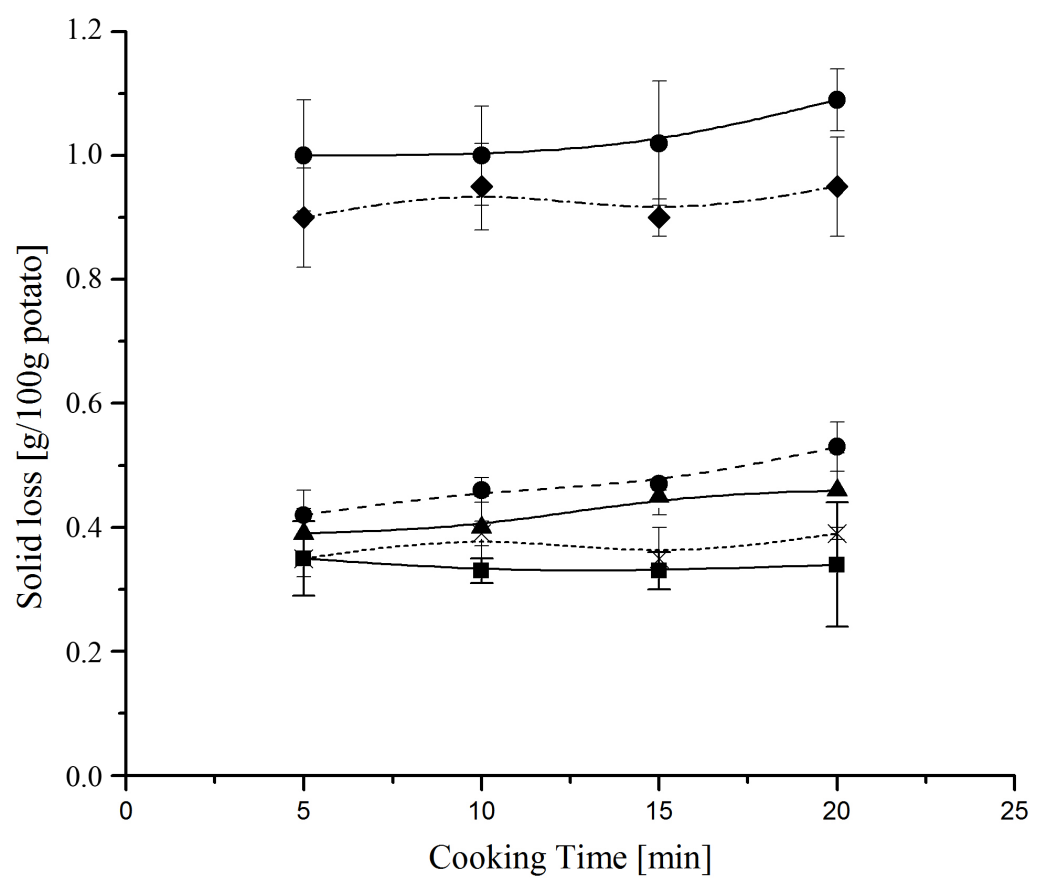

Spunta -

- Churquena $-\mathbf{A}-$ Runa -

(a)

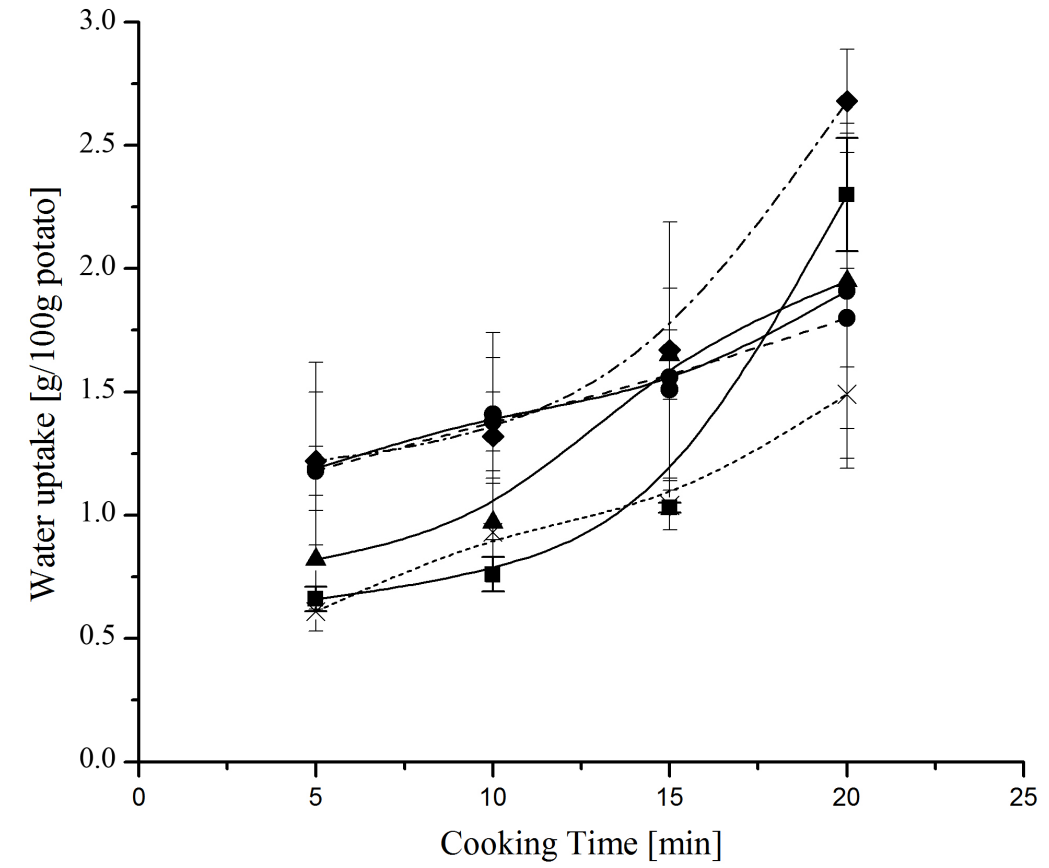

Spunta - -

Churquena $-\mathbf{A}-$ Runa -

(b)

Figure 1. Solids loss (a) and water uptake (b) vs cooking time of potato. Spunta (- $\bullet-)$,

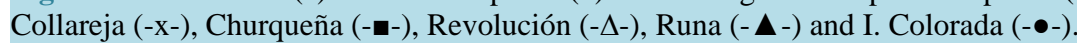

found retention factors between $56 \%$ and $97 \%$ in Peruvian native varieties. Different FR found for vitamin C may be related to the type of shell of each of the varieties studied, which could act as a protective barrier for the loss of nutrients. The variation in the content of vitamin $\mathrm{C}$ and the retention rates obtained are coincident with 
the values reported by Murniece et al. [27].

Cooking processes in wet conditions produce loss in the content of water-soluble vitamins and significantly improved the digestibility of starch, which must be made with controlled times. To minimize the loss of water soluble nutrients it is recommended eating the potato with shell by the barrier action exerted.

There is great interest to nutritionists and food industry to know properties of resistant starch (RS), which have led to extensive research on the contribution of the non-digestible carbohydrate components of the diet and their physiological implications. Colonic fermentation, bacterial growth, the post-prandial blood glucose level, intestinal transit time and the energy values of foods are affected by the presence of RS. The RS content in raw potatoes is determined by the physical encapsulation of starch granules. The boiling process modifies the resistant starch in food. Table 3 shows the content of total starch and resistant starch in raw and boiled potatoes. The total starch content is higher in all of the Andean potato varieties (13.53 - $18.70 \mathrm{~g} / 100 \mathrm{~g})$ than in the variety of reference $(12.61 \mathrm{~g} / 100 \mathrm{~g})$. The content of resistant starch decreases in all of the varieties when potatoes are boiled. Probably, due to the heat treatment causes the loose of granule structure, starch gelatinizes and its bonds are more exposed to enzymatic action. When cooked potatoes are stored, the content of RS increases again; in some cases, reaching values higher than those found in raw potatoes.

The increase of RS during stored of boiled potatoes could be attributed to the retrogradation of amylose, although it has been demonstrated that amylopectin may also become retrograded and contribute to RS content [28]. While amylose retrogradation takes place in few hours, amylopectin requires days or weeks to complete this process [29]. All this shows that the amylose/amylopectin ratio is an important factor in the process of retrogradation and RS changes by cooking processes [30]. Retrograded starch structure becomes less accessible to the digestive enzymes, and so a digestibility decrease takes place [31].

\subsection{Deep-Frying}

Table 4 shows the moisture contents of the different varieties of raw and fried potatoes. The frying causes a decrease of the water content of the food, which is a characteristic of this cooking process [32].

Table 3. Total and resistant starch contents in raw and boiled potatoes.

\begin{tabular}{|c|c|c|c|c|}
\hline \multirow{2}{*}{ Variety } & \multirow{2}{*}{$\begin{array}{c}\text { Total starch }{ }^{\mathrm{a}}(\mathrm{g} / 100 \mathrm{~g}) \\
\text { wm }^{\mathrm{b}}\end{array}$} & $\mathrm{Raw}^{\mathrm{a}}$ & Boiled $^{\mathrm{a}}$ & Boiled and stored $^{\mathrm{a}}$ \\
\hline & & \multicolumn{3}{|c|}{ Resistant starch (g/100g) wm ${ }^{\mathrm{b}}$} \\
\hline Spunta & $12.61 \pm 0.22$ & $2.47 \pm 0.07$ & $0.23 \pm 0.05$ & $2.85 \pm 0.17$ \\
\hline Revolución & $16.47 \pm 0.15$ & $4.58 \pm 0.18$ & $0.54 \pm 0.04$ & $0.97 \pm 0.10$ \\
\hline Churqueña & $18.70 \pm 1.01$ & $0.71 \pm 0.07$ & $0.50 \pm 0.04$ & $0.86 \pm 0.02$ \\
\hline Runa & $15.66 \pm 1.24$ & $0.90 \pm 0.10$ & $0.30 \pm 0.05$ & $0.79 \pm 0.01$ \\
\hline Imilla Colorada & $13.53 \pm 0.08$ & $1.44 \pm 0.12$ & $0.14 \pm 0.02$ & $0.73 \pm 0.15$ \\
\hline Collareja & $15.82 \pm 0.27$ & $0.90 \pm 0.14$ & $0.15 \pm 0.03$ & $1.88 \pm 0.30$ \\
\hline
\end{tabular}

${ }^{\mathrm{a}}$ Mean \pm standard deviation; $\mathrm{n}=3$; ${ }^{\mathrm{b}}$ Wet mater.

Table 4. Moisture loss and fat absorption of fried potatoes.

\begin{tabular}{|c|c|c|}
\hline \multirow{2}{*}{ Variety } & Moisture loss & Fat absorption \\
\hline & \multicolumn{2}{|c|}{$(\mathrm{g} / 100 \mathrm{~g} \text { potato })^{\mathrm{a}}$} \\
\hline Spunta & $19.63 \pm 0.20$ & $2.63 \pm 0.02$ \\
\hline Collareja & $25.21 \pm 0.16$ & $4.00 \pm 0.06$ \\
\hline Revolución & $20.80 \pm 0.11$ & $3.62 \pm 0.09$ \\
\hline Churqueña & $21.82 \pm 0.21$ & $3.91 \pm 0.10$ \\
\hline I .Colorada & $24.36 \pm 0.17$ & $3.61 \pm 0.01$ \\
\hline Runa & $27.41 \pm 0.27$ & $3.43 \pm 0.04$ \\
\hline
\end{tabular}

${ }^{\mathrm{a}}$ Mean \pm standard deviation; $\mathrm{n}=3$. 
The fat content of raw and fried potatos found (Table 1) are lower than those reported by Ooko \& Kabira [33] who obtained values between 7.51 to $8.81 \mathrm{~g}$ lipid/100g of potatoes for Kenyan varieties. In Table 4 it can be observed that the oil absorption was between 2.63 to $4.00 \mathrm{~g}$ of oil/100g of raw potato for the varieties studied. These values are lower than those reported by Bognar [34] who found for potato chips, croquettes, tortilla potatoes and potatoes fries on depth, values between 4.5 and $10 \mathrm{~g}$ oil $/ 100 \mathrm{~g}$ of potatoes.

Moisture loss and fat absorption (Table 4) by the frying process produced an increment in energy value between $92 \%$ and $148 \%$ according to variety.

\subsection{Textural Properties}

To evaluate the textural properties of cooked potatoes imitative type tests were used, which simulate mastication using mechanical instruments being the most used the Texture Profile Analysis (TPA). The cooking time was determined by analyzing the behavior of the compression strength as a function of time that tubers are kept at boiling. When the compressive strength is kept constant it is considered that the tubers are cooked and apt to consume. Figure 2 shows that the compression strength for the Runa and Spunta varieties remains constant after 15 minutes of boiling, which indicates that it is the adequate cooking time, while the cooking time for the Collareja variety is 20 minutes, and the Imilla Colorada, Churqueña and Revolución varieties take a shorter time (10 minutes). Andean potatoes require shorter cooking times than the Kufri Jyoti and Pukharj varieties (24 and 30 minutes) [15]. Even with shorter cooking times, the Andean varieties require greater compression strength with respect to the values reported by Kaur et al. [15] to achieve a thickness reduction of $50 \%$. In this work it is not found a correlation between the fracture strength and the starch content as Segnini et al. [35] informed.

Figure 3 and Figure 4 show the fracture strength and hardness curve of the potatoes according to cooking time, respectively. No significant differences are observed between the Andean and Spunta varieties at the initial or final stages, but there are differences in fracture strength and hardness performance during the intermediate stages.

Both parameters exhibit the same behavior; remaining high until 10 minutes for Andean varieties while for Spunta variety it falls faster. For Rune variety fracture strength drops at 5 min and then remains practically con-

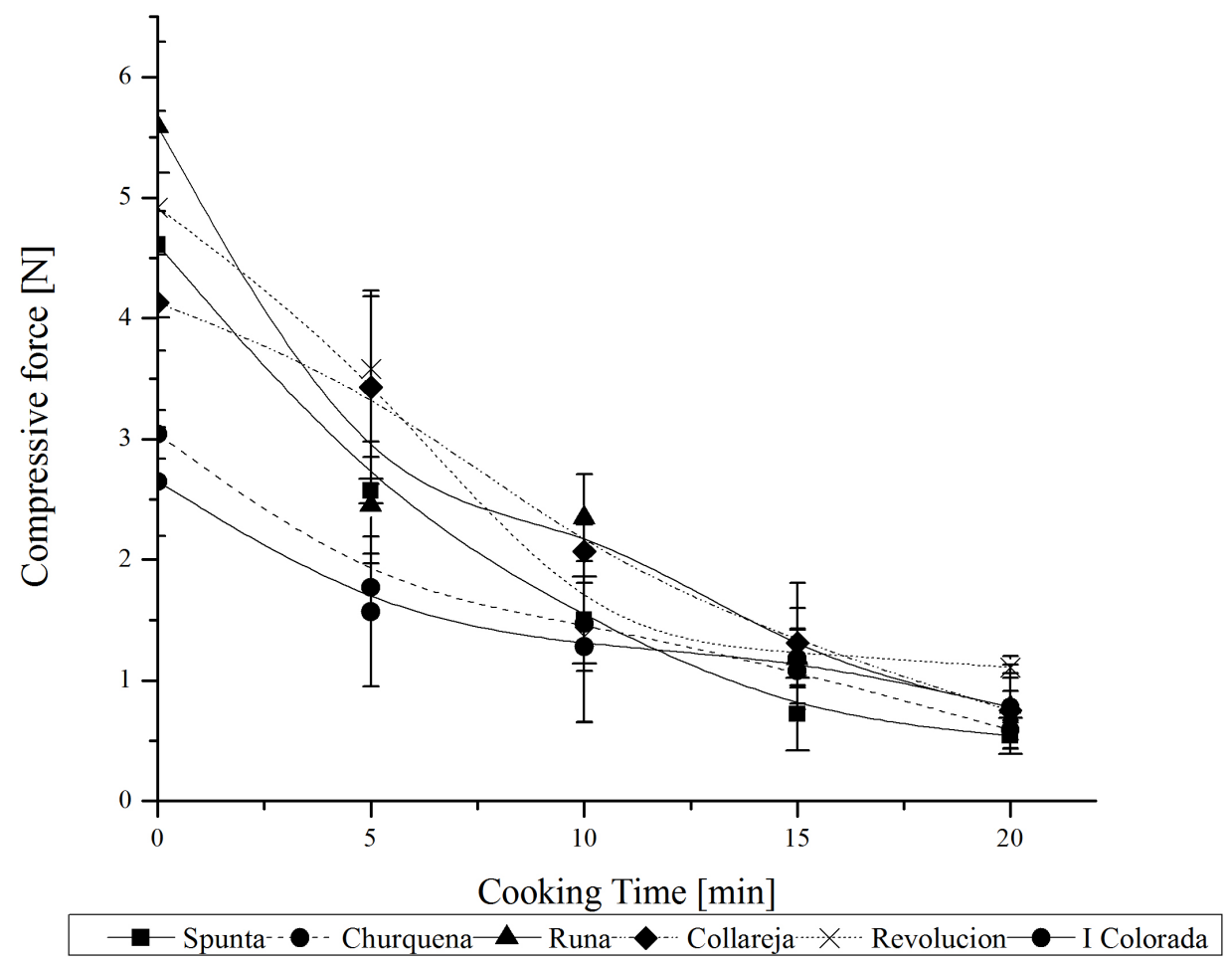

Figure 2. Effect of cooking time on compressive force of cooked potatoes. Spunta (- -), Collareja

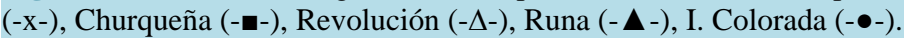




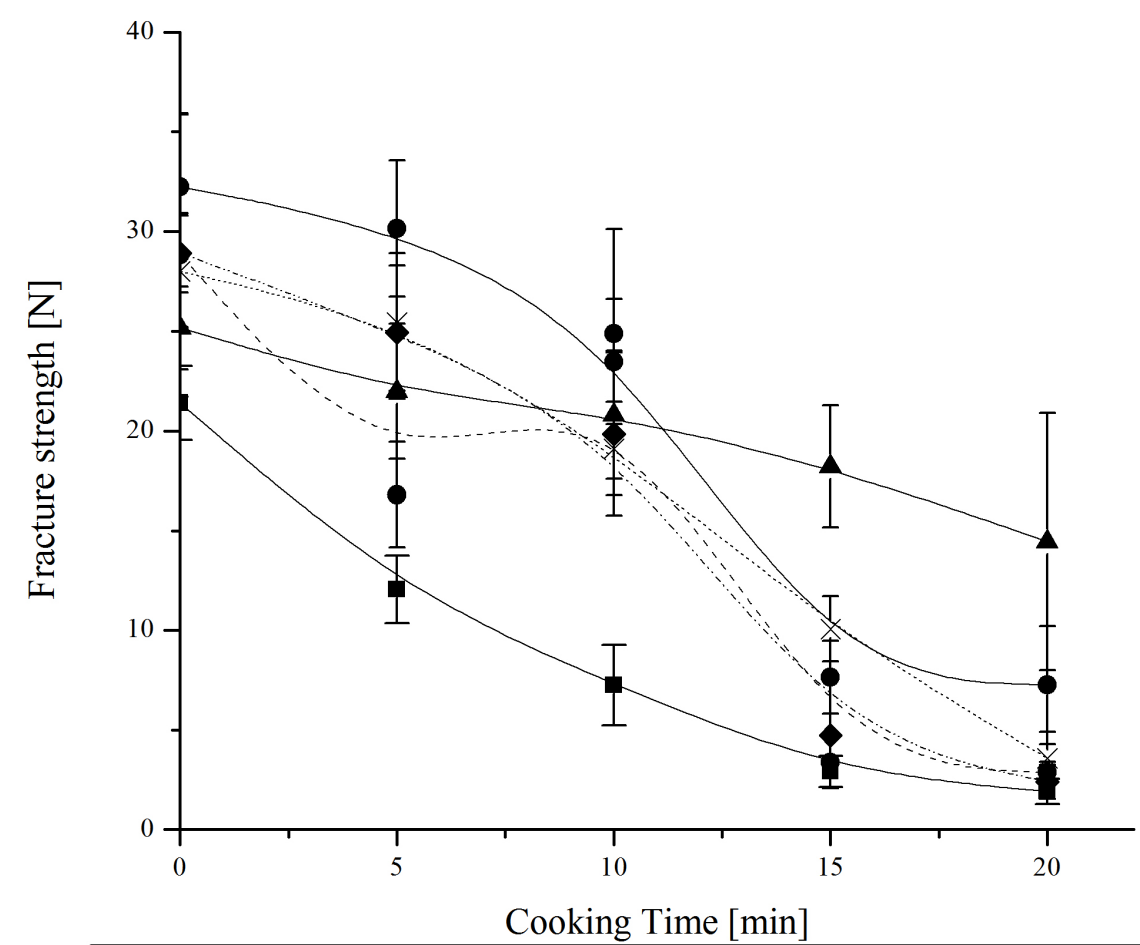

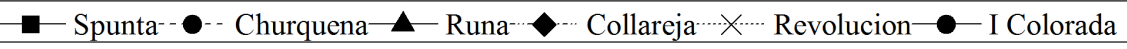

Figure 3. Fracture strength vs cooking time of potato vs cooking time of Spunta (- $\bullet)$, Collareja

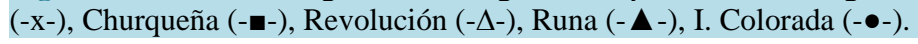

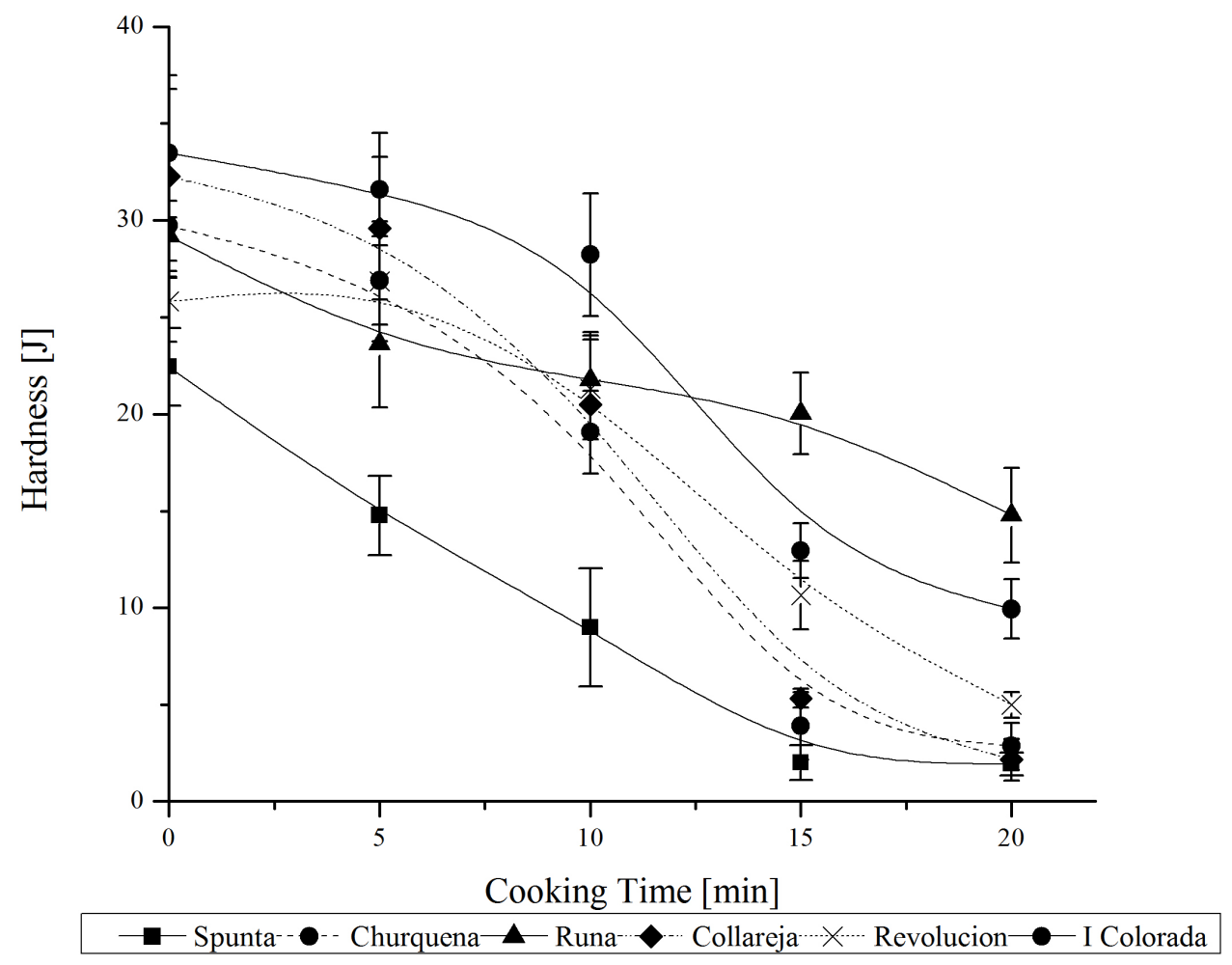

Figure 4. Hardness vs cooking time of potato vs cooking time of Spunta (- $\bullet-)$, Collareja (-x-),

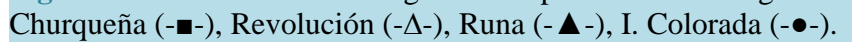


stant. The Spunta variety presents the lowest initial fracture strength although the difference with respect to the Andean varieties is not significant.

According to García-Segovia et al. [36] hardness can be defined as the strength needed to break the potato with the front teeth during mastication. The hardness values for Andean and Spunta varieties are similar to those found by Kaur et al. [15].

Adhesiveness may be related to the strength needed to remove the potato that remains adhered to the palate and teeth after mastication [36]. Table 5 shows that adhesiveness values increase with cooking time for all varieties since it is related to starch gelatinization. The values at the end of cooking are lower $(-0.10$ to $-0.17 \mathrm{~J})$ than those found by Kaur et al. [15] $\left(2.17 \times 10^{-4}\right.$ to $\left.8.99 \times 10^{-4} \mathrm{~J}\right)$ and greater than those informed by Garcia Segovia et al. [36] (-1.4 J).

Table 5 shows that when starting the boiling process there are no significant differences in adhesiveness between Spunta and Andean varieties. The Revolution and Runa varieties at 5 minutes of cooking show significantly differences from the other varieties which disappear after 20 minutes of boiling.

According to Garcia Segovia et al. [36], the increment in adhesiveness is related to starch gelatinization. According to Verlinden et al. [37] changes in texture in cooked potatoes are due to factors such as the reduction of cell rigidity, as well as starch gelatinization and weakening of the union of the cell wall.

Figure 1(a) shows the water absorption values for different cooking time batches. These values increase with cooking time for all varieties.

The amount of water absorbed is less than $3 \%$ at 20 min for reference and Andean varieties, and are slightly lower than those reported by Kaur et al. [15] for Hindus varieties, which vary between 3.03\% and 5.21\%.

The loss of soluble solids remains constant throughout the cooking cycle (Figure 1(b)). All the varieties display lower values than those found by Kaur et al. [15] (3.54\% - 5.8\%). This may be due to the potatoes were boiled with their skin while Kaur et al. [15] worked with peeled tubers.

Water absorption is inversely proportional to the preservation of nutrients. Higher water absorption increases the probability of nutrients to be solubilized and the loss is higher during cooking (boiling) [27]. The low values of soluble solids loss in boiled potatoes would indicate that the probability of nutrient losses by leaching and solubilization are low. All potato varieties behaved similarly, no significant differences were found in the values of soluble solids loss of water absorption.

\section{Conclusions}

The boiling process affects the composition of the Andean potato producing losses of vitamin C; the cooking by frying destroys vit $\mathrm{C}$ and increases the energy value of fried food; the increase depends on the variety of the potato. It can also be affirmed that the boiling process decreases the RS content in different varieties of potatoes; and that during storage at $4^{\circ} \mathrm{C}$ it increases again.

Texture analysis of boiled potatoes shows that there is no difference between boiled Andean varieties and reference variety.

Table 5. Adhesiveness of the different varieties of boiled potatoes.

\begin{tabular}{|c|c|c|c|c|c|}
\hline \multirow{2}{*}{ Variety } & \multicolumn{5}{|c|}{ Adhesiveness $[\mathrm{J}]^{\mathrm{a}}$} \\
\hline & 0 min & $5 \min$ & $10 \mathrm{~min}$ & 15 min & 20 min \\
\hline Spunta & $-0.75 \pm 0.17$ & $-0.20 \pm 0.56$ & $-0.23 \pm 0.86$ & $-0.13 \pm 0.06$ & $-0.10 \pm 0.04$ \\
\hline Revolución & $-0.56 \pm 0.24$ & $-0.56 \pm 0.18$ & $-0.23 \pm 0.61$ & $-0.22 \pm 0.09$ & $-0.17 \pm 0.02$ \\
\hline Churqueña & $-0.62 \pm 0.20$ & $-0.20 \pm 0.58$ & $-0.24 \pm 0.50$ & $-0.23 \pm 0.09$ & $-0.16 \pm 0.03$ \\
\hline Runa & $-0.77 \pm 0.32$ & $-0.56 \pm 0.13$ & $-0.24 \pm 0.85$ & $-0.21 \pm 0.02$ & $-0.16 \pm 0.06$ \\
\hline I Colorada & $-0.69 \pm 0.14$ & $-0.19 \pm 0.94$ & $-0.36 \pm 0.19$ & $-0.23 \pm 0.07$ & $-0.13 \pm 0.07$ \\
\hline Collareja & $-0.78 \pm 0.10$ & $-0.34 \pm 0.17$ & $-0.25 \pm 0.04$ & $-0.28 \pm 0.01$ & $-0.15 \pm 0.08$ \\
\hline
\end{tabular}

${ }^{\mathrm{a}}$ The results are presented as average \pm standard deviation; $\mathrm{n}=3$. 


\section{Acknowledgements}

This work was conducted with financial support from the Council of Science and Technology of the National University of Tucumán (CIUNT) and National Agency for Science and Technology.

\section{References}

[1] FAO (2009) FAO Statistical Database, Supply Utilization Account. http://faostat.fao.org

[2] Buckenhuskes, H.J. (2005) Nutritional Relevant Aspect of Potatoes and Potato Constituents. In: Haverkort, A.J. and Struik, P.C., Eds., Potato in Progress-Science Meets Practices, Wageningen Academic Publishers, Wageningen, The Netherlands, 17-26.

[3] Leo, L., Leone, A., Longo, C., Lombardi, D.A., Raimo, F. and Zacheo, G. (2008) Antioxidant Compounds and Antioxidant Activity in "Early Potatoes”. Journal of Agricultural and Food Chemistry, 56, 4154-4163. http://dx.doi.org/10.1021/jf073322w

[4] Delaplance, P., Rojas-Beltran, J., Frettinger, P., du Jardin, P. and Fauconnier, M.L. (2008) Oxylipin Profile and Antioxidant Status of Potato Tubers during Extended Storage at Room Temperature. Plant Physiology and Biochemistry, 46, 1077-1084. http://dx.doi.org/10.1016/j.plaphy.2008.09.001

[5] FAO (2008) Año internacional de la papa 2008, nueva luz sobre un tesoro enterrado. Organización de las Naciones Unidas para la Agricultura y la Alimentación.

[6] FAO (2012) Sustainable Diets and Biodiversity. Directions and Solutions for Policy, Research and Action. Burlingame, B. and Dernini, S., Eds., Nutrition and Consumer Protection Division FAO, Roma, 309.

[7] Ciok, J. and Dolna, A. (2006) The Role of Glycemic Index Concept in Carbohydrate Metabolism. Przeglad Lekarski, 63, 287-291.

[8] Ferrer-Mairal, A., Penalva-Lapuente, C., Iglesia, I., Urtasun, L., De Miguel-Etayo, P., Remon, S., Cortes, E. and Moreno, L.A. (2012) In Vitro and in Vivo Assessment of the Glycemic Index of Bakery Products: Influence of the Reformulation of Ingredients. European Journal of Nutrition, 51, 947-954. http://dx.doi.org/10.1007/s00394-011-0272-6

[9] Englyst, H.N. and Hudson, G.J. (1996) The Classification and Measurement of Dietary Carbohydrates. Food Chemistry, 57, 15-21. http://dx.doi.org/10.1016/0308-8146(96)00056-8

[10] Perera, A., Meda, V. and Tyler, R.T. (2010) Resistant Starch: A Review of Analytical Protocols for Determining Resistant Starch and of Factors Affecting the Resistant Starch Content of Foods. Food Research International, 43, 19591974. http://dx.doi.org/10.1016/j.foodres.2010.06.003

[11] Brown, I. (2004) Applications and Uses of Resistant Starch. Journal of AOAC International, 87, 727-732.

[12] Fuentes-Zaragoza, E., Riquelme-Navarrete, M.J., Sánchez-Zapata, E. and Pérez-Álvarez, J.A. (2010) Resistant Starch as Functional Ingredient: A Review. Food Research International, 43, 931-942. http://dx.doi.org/10.1016/j.foodres.2010.02.004

[13] Pęksa, A., Apeland, J., Gronnerod, S. and Magnus, E.-M. (2002) Comparison of the Consistencies of Cooked Mashed Potato Prepared from Seven Varieties of Potatoes. Food Chemistry, 76, 311-317. http://dx.doi.org/10.1016/S0308-8146(01)00278-3

[14] McGregor, I. (2007) Chapter I-The Fresh Potato Market. In: Vreugdenhil, D.J., Bradshaw, D., Gebhardt, C., Govers, F., Mackerron, D.K.L., Taylor, M.A. and Ross, H.A., Eds., Potato Biology and Biotechnology, Elsevier Science B.V., Amsterdam, 3-26.

[15] Kaur, L., Singh, N., Sodhi, N.S. and Gujral, H.S. (2002) Some Properties of Potatoes and Their Starches I. Cooking, Textural and Rheological Properties of Potatoes. Food Chemistry, 79, 177-181. http://dx.doi.org/10.1016/S0308-8146(02)00129-2

[16] Pons, M. and Fiszman, S.M. (1996) Instrumental Texture Analysis with Particular References to Gelled System. Journal of Texture Studies, 27, 597-624. http://dx.doi.org/10.1111/j.1745-4603.1996.tb00996.x

[17] Rosenthal, A. (2001) Textura de los Alimentos. Medida y percepción. Acribia, Editorial, España, 299 p.

[18] Burgos, G., Amoros, W., Mu, M.L., Sosa, P., Cayhualla, E., Sanchez, C., Díaz, C. and Bonierbale, M. (2013) Total Phenolic, Total Anthocyanin and Phenolic Acid Concentrations and Antioxidant Activity of Purple-Fleshed Potatoes as Affected by Boiling. Journal of Food Composition and Analysis, 30, 6-12. http://dx.doi.org/10.1016/j.jfca.2012.12.001

[19] Ratnajothi, H. (2010) The Impact of Heat-Moisture Treatment on Molecular Structures and Properties of Starches Isolated from Different Botanical Sources. Critical Reviews in Food Science and Nutrition, 50, 835-847. http://dx.doi.org/10.1080/10408390903001735

[20] AOAC (1995) Official Methods of Analysis of Association of Official Analytical Chemists. 16th Edition, Association of Official Analytical Chemists AOAC International, Arlington. 
[21] Correa de Souza, M., Toledo Benassi, M., Fraxino de Almeida Meneghel, R. and dos Santos Ferreira da Silva, R.S. (2004) Stability of Unpasteurized and Refrigerated Orange Juice. Brazilian Archives of Biology and Technology, 47, 391-397. http://dx.doi.org/10.1590/S1516-89132004000300009

[22] McCleary, B.V., Gibson, T.S. and Mugford, D.C. (1997) Measurement of Total Starch in Cereal Products by Amyloglucosidase- $\alpha$-Amylase Method: Collaborative Study. Journal of AOAC International, 80, 571-579.

[23] Goñi, I., García-Diz, L., Mañas, E. and Saura-Calixto, F. (1996) Analysis of Resistant Starch: A Method for Foods and Food Products. Food Chemistry, 56, 445-449. http://dx.doi.org/10.1016/0308-8146(95)00222-7

[24] Bognár, A. and Piekarski, J. (2000) Guidelines for Recipe Information and Calculation of Nutrient Composition of Prepared Foods (Dishes). Journal of Food Composition and Analysis, 13, 391-410. http://dx.doi.org/10.1006/jfca.2000.0922

[25] Jimenez, M.E., Rossi, A. and Sammán, N. (2009) Phenotypic, Agronomic, Nutritional Characteristics of Seven Varieties of Andean Potatoes. Journal of Food Composition and Analysis, 22, 613-616. http://dx.doi.org/10.1016/j.jfca.2008.08.004

[26] Burgos, G., Auqui, S., Amoros, W., Salas, E. and Bonierbale, M. (2009) Ascorbic Acid Concentration of Native Andean Potato Varieties as Affected by Environment, Cooking and Storage. Journal of Food Composition and Analysis, 22, 533-538. http://dx.doi.org/10.1016/j.jfca.2008.05.013

[27] Murniece, I., Karklina, D., Galoburda, R., Santare, D., Skrabule, I. and Costa, H.S. (2011) Nutritional Composition of Freshly Harvested and Stored Latvian Potato (Solanum tuberosum L.) Varieties Depending on Traditional Cooking Methods. Journal of Food Composition and Analysis, 24, 699-710. http://dx.doi.org/10.1016/j.jfca.2010.09.005

[28] Thompson, D.B. (2000) Strategies for the Manufacture of Resistant Starch. Trends in Food Science \& Technology, 11, 245-253. http://dx.doi.org/10.1016/S0924-2244(01)00005-X

[29] Rosin, P.M., Lajolo, F.M. and Menezes, E.W. (2002) Measurement and Characterization of Dietary Starches. Journal of Food Composition and Analysis, 15, 367-377. http://dx.doi.org/10.1006/jfca.2002.1084

[30] Copeland, L., Blazek, J., Salman, H. and Tang, M.C. (2009) Form and Functionality of Starch. Food Hydrocolloid, 23, 1527-1534. http://dx.doi.org/10.1016/j.foodhyd.2008.09.016

[31] Parada, J. and Aguilera, J.M. (2012) Effect of Native Crystalline Structure of Isolated Potato Starch on Gelatinization Behavior and Consequently on Glycemic Response. Food Research International, 45, 238-243. http://dx.doi.org/10.1016/j.foodres.2011.10.042

[32] Juárez, M.D., Osawa, C.C., Acuña, M.E., Sammán, N. and Gonçalves, L.A.G. (2011) Degradation in Soybean Oil, Sunflower Oil and Partially Hydrogenated Fats after Food Frying, Monitored by Conventional and Unconventional Methods. Food Control, 22, 1920-1927. http://dx.doi.org/10.1016/j.foodcont.2011.05.004

[33] Ooko, G.A. and Kabira, J.N. (2011) Suitability of Three Newly Released Kenyan Potato Varieties for Processing into Crisps and French Fries. African Journal of Food, Agriculture, Nutrition and Development, 11, 5266-5281.

[34] Bognar, A. (1998) Comparative Study of Frying to Other Cooking Techniques Influence on the Nutritive Value. Grasas $y$ Aceites: Revista Bimestral de Información Científica y Técnica, 49, 250-260.

[35] Segnini, S., Dejmek, P. and Öste, R. (1999) Reproducible Texture Analysis of Potato Chips. Journal of Food Science, 64, 309-312. http://dx.doi.org/10.1111/j.1365-2621.1999.tb15889.x

[36] García-Segovia, P., Andres-Bello, A. and Martínez-Monzo, J. (2008) Textural Properties of Potatoes (Solanum tuberosum L., cv. Monalisa) as Affected by Different Cooking Processes. Journal of Food Engineering, 88, 28-35. http://dx.doi.org/10.1016/j.jfoodeng.2007.12.001

[37] Verlinden, B.E., Nicolaï, B.M. and De Baerdemaerker, J. (1995) The Starch Gelatinization in Potatoes during Cooking in Relation to the Modeling of Texture Kinetics. Journal of Food Engineering, 24, 165-179. http://dx.doi.org/10.1016/0260-8774(94)P2641-H 